\title{
Abnormal Reference Range
}

National Cancer Institute

\section{Source}

National Cancer Institute. Abnormal Reference Range. NCI Thesaurus. Code C78802.

Reported values outside the typical or expected range. 